\title{
Corrections
}

\section{Fulminant liver failure during interferon beta treatment of multiple sclerosis}

Recently, Yoshida et al. ${ }^{1}$ reported a patient who developed fulminant liver failure, requiring urgent liver transplantation, 7 weeks after commencing interferon $\beta$-1a (Rebif, Serono-Canada, Oakville, Ontario, Canada). The patient received a liver transplant in September 2000 and the authors have received new information that she had been started on nefazodone (Serzone, Bristol-Myers Squibb Canada, Montreal, Quebec) in February of 2000. Nefazodone has recently been reported in association with acute liver failure. $^{2,3}$ The manufacturer of nefazodone has reported 23 cases of liver failure and 109 cases of hepatic adverse events out of 8.3 million users of this drug worldwide. ${ }^{4}$ The patient's liver enzymes were stable prior to starting interferon $\beta$-1a and two-thirds of nefazodone-associated liver failure occurred within 4 months. ${ }^{4}$ Interferon $\beta$-1a appears to be temporally implicated in the patient's liver failure but the authors cannot exclude the possibility that nefazodone may have been a factor or cofactor. The authors regret that they were unaware of this patient's nefazodone use until their paper appeared in print.

\section{References}

1. Yoshida EM, Rasmussen SL, Steinbrecher UP, et al. Fulminant liver failure during interferon beta treatment of multiple sclerosis. Neurology 2001;56:1416.

2. Aranda-Michael J, Koehler A, Bejarano PA, et al. Nefazodone-induced liver failure: report of three cases. Ann Intern Med 1999;130:285-288.

3. Schirren CA, Garetton G. Nefazodone-induced acute liver failure. Am J Gastroenterol 2000;95:1596-1597. Letter.

4. Esposito V, King L. Important safety information on Nefazodone HCL: severe and serious hepatic events. PharmGram. Priority Communications from Canada's Pharmaceutical Industry. June 20, 2001.

\section{A 24-week, randomized, double-blind study of donepezil in moderate to severe Alzheimer's disease}

The authors of the article "A 24-week, randomized, double-blind study of donepezil in moderate to severe Alzheimer's disease" (Neurology 2001;57:613-620) would like to amend the disclosure in this article to add that between the time of submission (November 14, 2000) and publication of the article (August 28, 2001) in Neurology, honoraria received from the sponsor exceeded $\$ 10,000$ for the past year. All other aspects of the disclosure are unchanged. 


\section{Neurology}

\section{To: Fulminant liver failure during interferon beta treatment of multiple sclerosis Neurology 2001;57;2153}

DOI 10.1212/WNL.57.11.2153

This information is current as of December 11, 2001

$\begin{array}{ll}\begin{array}{l}\text { Updated Information \& } \\ \text { Services }\end{array} & \begin{array}{l}\text { including high resolution figures, can be found at: } \\ \text { http://n.neurology.org/content/57/11/2153.1.full }\end{array} \\ \text { Permissions \& Licensing } & \begin{array}{l}\text { Information about reproducing this article in parts (figure } \\ \text { in its entirety can be found online at: } \\ \text { http://www.neurology.org/about/about_the_journal\#perm }\end{array} \\ \text { Reprints } & \begin{array}{l}\text { Information about ordering reprints can be found online: } \\ \text { http://n.neurology.org/subscribers/advertise }\end{array}\end{array}$

Neurology ${ }^{\circledR}$ is the official journal of the American Academy of Neurology. Published continuously since 1951, it is now a weekly with 48 issues per year. Copyright. All rights reserved. Print ISSN: 0028-3878.

Online ISSN: 1526-632X.

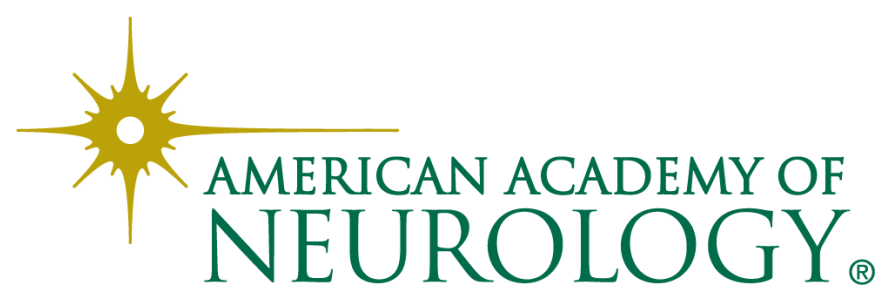

